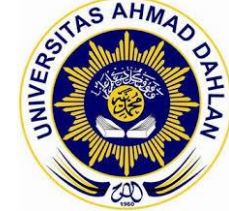

BERKALA FISIKA INDONESIA

Jurnal IImiah Fisika, Pembelajaran dan Aplikasinya

http://journal.uad.ac.id/index.php/BFl/index 2085-0409 (Print) | 2550-0465 (online)

\title{
Lembar kerja peserta didik dengan konsep TPACK pada pokok bahasan gelombang stasioner dan gelombang berjalan
}

\author{
Rosynanda Nur Fauziah ${ }^{1 *}$, Dwi Sulisworo ${ }^{2}$ \\ 1 Pendidikan Fisika, Fakultas Keguruan dan Ilmu Pendidikan, Universitas Ahmad Dahlan, Indonesia \\ 2 Magister Pendidikan Fisika, Fakultas Keguruan dan Ilmu Pendidikan, Universitas Ahmad Dahlan, Indonesia \\ Email: rosynanda1907041002@webmail.uad.ac.id* \\ * Penulis korespondensi
}

\begin{tabular}{l}
\hline Informasi artikel \\
\hline Sejarah artikel: \\
Dikirim \\
Revisi \\
Diterima
\end{tabular}

\section{Kata kunci:}

\section{LKPD}

TPACK

Penelitian pengembangan

Model 4-D

\begin{abstract}
ABSTRAK
Penelitian ini bertujuan untuk menghasilkan lembar kerja peserta didik dengan menggunakan konsep technological pedagogical and content knowledge. Penelitian ini merupakan jenis penelitian pengembangan dengan mengadopsi model 4-D. Tahapan pengembangan meliputi Define, Design, Development, dan Dissemination. Penelitian dilaksanakan pada bulan april 2019 dan melibatkan siswa kelas XI MIPA di SMA Muhammadiyah 7 Yogyakarta sebagai subyek. Data dikumpulkan menggunakan lembar angket validasi ahli media, ahli materi, dan juga respon siswa. Instrumen menggunakan skala jenis likert. Teknik analisis data yang digunakan dalam penelitian ini adalah deskriptif. Hasil pengembangan menunjukkan bahwa lembar kegiatan peserta didik berbasis TPACK valid dan mendapat respon yang baik dari guru dan siswa.
\end{abstract}

This is an open access article under the CC-BY-SA license

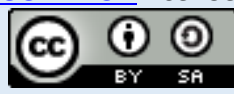

\section{ABSTRACT}

Student worksheets with the TPACK concept on the subject of stationary waves and Traveling Waves. This study aims to produce student worksheets using the concept of technological pedagogical and content knowledge. This research is a type of development research by adopting the 4-D model. The development stages include Define, Design, Development, and Dissemination. The study was conducted in April 2019 and involved class XI MIPA students at SMA Muhammadiyah 7 Yogyakarta as subjects. Data were collected using validation questionnaire sheets from media experts, material experts, and student responses. The instrument uses a Likert type scale. The data analysis technique used in this research is descriptive. The development results show that the TPACK-based student activity sheets are valid and get good responses from teachers and students.

\section{How to Cite:}

Fauziah, R. N., \& Dwi Sulisworo. (2020). Lembar kerja peserta didik dengan konsep TPACK pada pokok bahasan gelombang stasioner dan gelombang berjalan. Berkala Fisika Indonesia: Jurnal Ilmiah Fisika, Pembelajaran dan Aplikasinya, 11(1), 24-31. 


\section{Pendahuluan}

Pendidikan adalah landasan pertumbuhan sumber daya manusia suatu negara. Pendidikan Nasional berfungsi untuk meningkatkan keterampilan dan membentuk karakter bangsa dan peradaban yang berintegritas dalam bentuk mencerdaskan kehidupan bangsa, sesuai dengan UU Sisdiknas No. 20 Tahun 2003. Pendidikan berupaya untuk membantu peserta didik mencapai potensi penuhnya sebagai manusia yang beriman dan bertakwa kepada Tuhan Yang Maha Esa, berakhlak mulia, berakhlak mulia, berakhlak mulia, cerdas, cakap, imajinatif, mandiri, demokratis, dan bertanggung jawab (Pratama \& Istiyono, 2015). Indonesia merupakan negara yang terbuka dan dapat menerima hal-hal baru atas perkembangan pendidikan pada setiap waktu, perkembangan pendidikan diharapkan dapat meningkatkan kesiapan mental bagi peserta didik untuk mencerdaskan kehidupan bangsa (Kadi, Awwaliyah, Nurul, \& Paiton, 2017).

Salah satu hal yang diperbuat untuk mencerdaskan kehidupan bangsa adalah terus memperbaharui kurikulum, dan kurikulum yang digunakan saat ini adalah kurikulum 2013 (Alawiyah, 2013). Puncak program 2013 adalah rangkaian penyempurnaan kurikulum berbasis kompetensi yang dimulai tahun 2004 dan diperpanjang pada tahun 2006 (KTSP). Akibatnya, memperbarui kurikulum sekolah menjadi kebutuhan yang tak terhindarkan (Nur \& Putri, 2013). Beberapa aspek atau ranah yang terkandung dalam kurikulum 2013 saling keterkaitan untuk pelaksanaan pembelajaran yang ada di dalam kelas, karena pembelajaran di dalam kelas yang baik dan efektif harus sesuai dan mengikuti kurikulum yang berlaku. Kurikulum yang berlaku di Indonesia termasuk dengan kurikulum 2013 banyak mendayagunakan aneka ragam sumber belajar salah satunya adalah lembar kerja peserta didik (Anggraini, Wahyuni, \& Lesmono, 2016).

Lembar Kerja Peserta Didik (LKPD) merupakan sumber belajar yang dapat digunakan guru untuk membantu siswa dalam mengerjakan Pekerjaan Rumah (PR). Karena LKPD saat ini dirasa sudah memadai oleh instruktur sebagai bahan ajar dan alat peraga yang digunakan oleh siswa, maka LKPD tersebut dapat digunakan sebagai rujukan dan sumber isi siswa selama proses pembelajaran (Fitriani, Bakri, \& Sunaryo, 2017). Lembar kerja peserta didik mempunyai peran penting dalam pembelajaran yaitu dapat membantu siswa untuk melakukan aktivitas secara mandiri maupun berkelompok dan dapat mempermudah siswa untuk memahami mata pelajaran yang diberikan oleh guru (Astuti \& Setiawan, 2013). Ada beberapa mata pelajaran yang membutuhkan observasi, pembuatan hipotesis, eksperimen, serta evaluasi yang memerlukan lembar kerja peserta didik yang sesuai dengan kebutuhan mata pelajaran tersebut (Usmeldi, 2015).

Fisika merupakan salah satu divisi ilmu pengetahuan alam yang mempelajari suatu fenomena ilmiah, yang meliputi kajian, teori, tes, dan penilaian data berdasarkan sikap ilmiah. Oleh karena itu, diperlukan LKPD agar siswa tidak sekedar menguasai fakta, ide, keyakinan, dan hukum untuk mempelajari fisika. Meskipun demikian, siswa diprediksi akan mampu menguasai semuanya melalui 
proses eksplorasi (Anggraini et al., 2016). Berdasarkan penjelasan sebelumnya, maka sangat penting untuk menyusun LKPD berdasarkan definisi yang benar, TPACK. TPACK menjelaskan keahlian gabungan dari setiap bidang pengetahuan yang dibahas, menekankan bagaimana teknologi dapat disesuaikan untuk memenuhi kebutuhan pedagogis untuk mengajarkan materi yang sesuai di lingkungan tertentu (Lin et al., 2012; Rosenberg \& Koehler, 2015; Rosyid, 2017).

Tujuan dari pengembangan ini adalah menghasilkan lembar kerja peserta didik menggunakan konsep TPACK. Dengan adanya penelitian ini diharapkan dapat digunakan sebagai referensi untuk menghasilkan bahan ajar yang inovatif, efektif, dan interaktif.

\section{Metode}

Pendekatan analisis R\&D akan digunakan dalam laporan ini. Item media pembelajaran tertentu dapat dikembangkan dengan menggunakan teknik pengujian $R \& D$, dan kemanjurannya dapat diuji (Haryati, 2012). Model 4-D yang diusulkan oleh Thiagarajan dan Semmel pada tahun 1974 digunakan dalam analisis ini sebagai model produksi. (Wahyudi, Hariyadi, \& Hariani, 2014). Model pengembangan 4-D dipilih untuk mengembangan media pembelajaran dengan menggunakan teknologi Augmented Reality. Model pengembangan 4-D disusun secara sistematis dengan urutan kegiatan yang dapat digunakan untuk mengembangkan sebuah media pembelajaran (Wardani \& Cholid, 2019). Model 4-D terbagi menjadi 4 tahapan yaitu Define (pendefinisian), Design (perencanaan), Development (pengembangan), and Dissemination (penyebaran) (Gorbi Irawan, nyoman Padmadewi, \& Putu Artini, 2018).

Siswa kelas XI Mipa yang berasal dari SMA Muhammadiyah 7 Yogyakarta telah dijadikan Subjek dalam penelitian. Penelitian ini dilaksanakan pada bulan April 2019. Data dikumpulkan menggunakan lembar angket validasi ahli media, ahli materi, dan juga respon siswa. Skala yang digunakan dalam instrumen berbentuk skala likert.

Metode pengolahan data digunakan untuk menghasilkan solusi berkualitas tinggi yang mengikuti kriteria keaslian, kegunaan, dan khasiat. Lembar validasi ahli dan angket jawaban siswa digunakan untuk membuat LKPD berdasarkan konsep TPACK. Teknik analisis data yang digunakan dalam penelitian ini adalah deskriptif sebagaimana ditunjukkan dalam persamaan 1. Teknik ini bertujuan untuk mendeskripsikan data yang telah terkumpul. Kriteria kelayakan mengacu pada Tabel 1.

$$
\begin{aligned}
& \text { Tabel 1. Kriteria penilaian produk } \\
& \bar{X}=\frac{\sum X}{N X_{i}}
\end{aligned}
$$

\begin{tabular}{cc}
\hline Kategori & Skor \\
\hline Sangat Baik (SB) & 4 \\
Baik (B) & 3 \\
Kurang (K) & 2 \\
Sangat Kurang (SK) & 1 \\
\hline
\end{tabular}


Dimana $\bar{X}$ merupakan skor rata-rata tiap kriteria, $X_{\mathrm{i}}$ adalah skor tiap butir pernyataan, $N$ adalah jumlah responden dan $\sum X$ adalah jumlah seluruh skor jawaban dari seluruh responden.

\section{Hasil dan Pembahasan}

Validasi Media

Hasil dari validator media menyatakan bahwa media sangat baik (SB) dan layak untuk digunakan dapat dilihat Gambar 1.

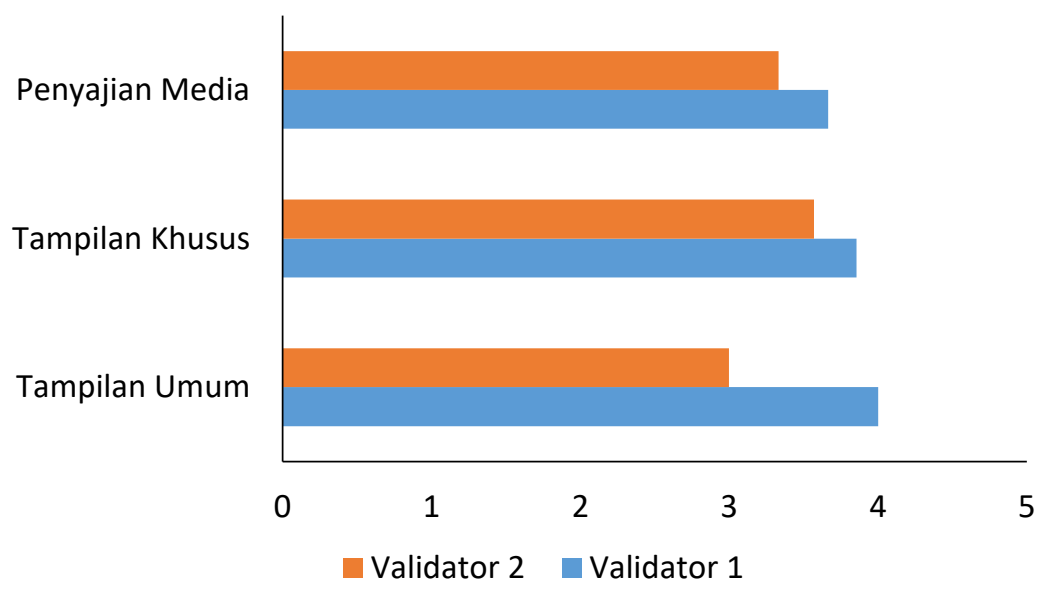

Gambar 1. Grafik hasil validasi media

Berdasarkan Gambar 1 penilaian untuk validasi media meliputi aspek tampilan umum, aspek tampilan khusus, dan aspek penyajian media. Pada aspek tampilan umum validator 1 memberikan nilai 4,00 dan validator 2 memberikan nilai 3,00, kemudian pada aspek tampilan khusus validator 1 memberikan nilai 3,857 dan validator 2 memberikan nilai 3,571, yang terakhir pada aspek penyajian media validator 1 memberikan nilai 3,666 dan validator 2 memberikan nilai 3,33. Sedangkan untuk nilai keseluruhan rata-rata tiap aspek yang diberikan oleh validator dinyatakan sangat baik yaitu 3,841 (validator 1) dan 3,300 (validator 2). Hal tersebut sudah memenuhi syarat kelayakan yang diberikan oleh validator, validator menyatakan bahwa media layak dan dapat diseberluaskan kepada peserta didik dengan hasil validasi rentang nilai >3,25 - 4 dan dinyatakan sangat baik (SB). Kemudian untuk hasil rata-rata yang diberikan oleh kedua validator pada setiap aspek, tersaji dalam Gambar 2.

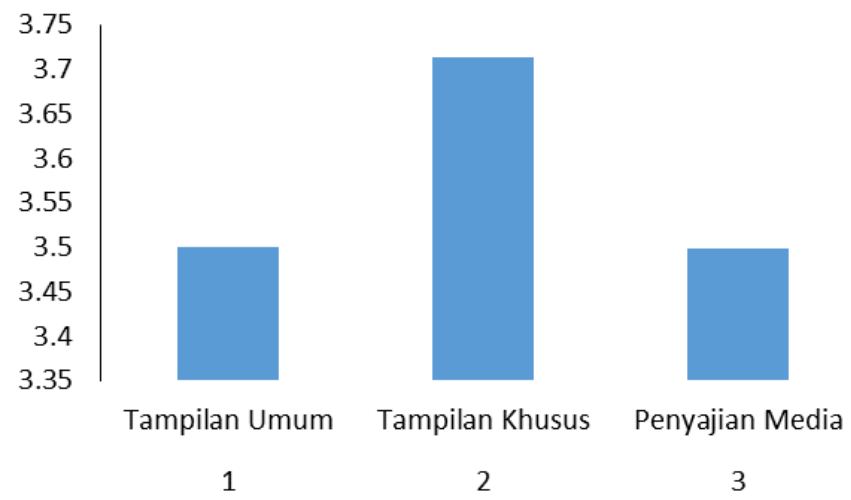

Gambar 2. Grafik rata-rata penilaian tiap aspek pada validasi media 
Gambar 2 menampilkan hasil rata-rata penilaian dua validator ahli media pada setiap aspek yang tersaji dalam validasi media, pada aspek tampilan umum memperoleh hasil rata-rata sebesar 3,5, kemudian aspek tampilan khusus memperoleh nilai rata-rata 3,714, dan aspek penyajian media memperoleh hasil rata-rata 3,498.

\section{Validasi Materi}

Hasil validasi materi yang diberikan oleh validator 1 dan validator 2 menyatakan bahwa materi sangat baik. Materi tersebut dibenahi kembali sesuai saran yang diberikan dari setiap validator atau dinamakan dengan revisi produk, revisi produk dilakukan supaya materi yang ada dalam pengembangan lembar kerja peserta didik dapat menjadi materi yang lebih baik dan juga relevan. Materi yang sudah direvisi diserbarkan kepada peserta didik. Berdasarkan hasil validasi materi yang telah dilakukan oleh validator ahli materi menyatakan bahwa materi sangat baik (SB) seperti pada Gambar 3.

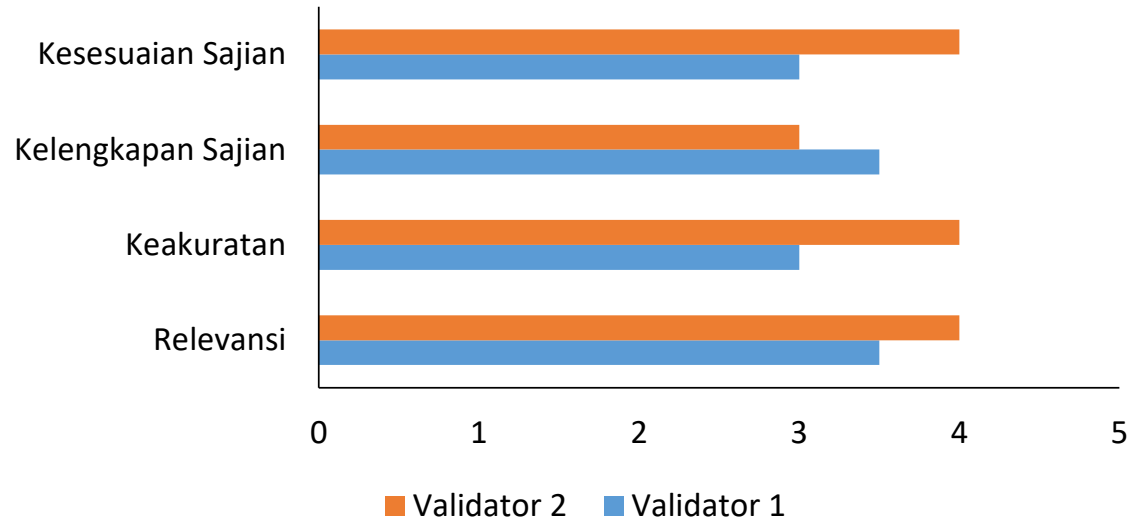

Gambar 3. Grafik hasil validasi materi

Data hasil validasi materi pada Gambar 3, meliputi aspek kesesuaian sajian, kelengkapan sajian, keakuratan, dan relevansi yang diberikan oleh tiap validator. Pada aspek relevansi tiap validator memberikan nilai 3,5 (Validator 1) dan 4,00 (Validator 2). Aspek keakuratan nilai yang diberikan validator 1 adalah 3,00 dan validator 2 adalah 4,00. Aspek kelengkapan sajian validator 1 dan 2 memberikan nilai masing-masing 3,5 dan 3,00. Terakhir, aspek sesuaian sajian validator 1 memberikan nilai 3,00 dan validator 2 memberikan nilai 4,00. Sedangkan untuk nilai dari keseluruhan aspek yaitu 3,25 (Validator 1) dan 3,75 (Validator 2). Hasil tersebut sudah memenuhi syarat dan sesuai dengan skor yang diberikan oleh validator dalam rentang nilai >3,25 - 4 dan dinyatakan sangat baik (SB), kemudian dengan hasil yang diberikan oleh validator produk dapat disebarluaskan kepada peserta didik. Kemudian rata-rata yang diberikan oleh kedua validator pada setiap aspek, tersaji dalam Gambar 4. 


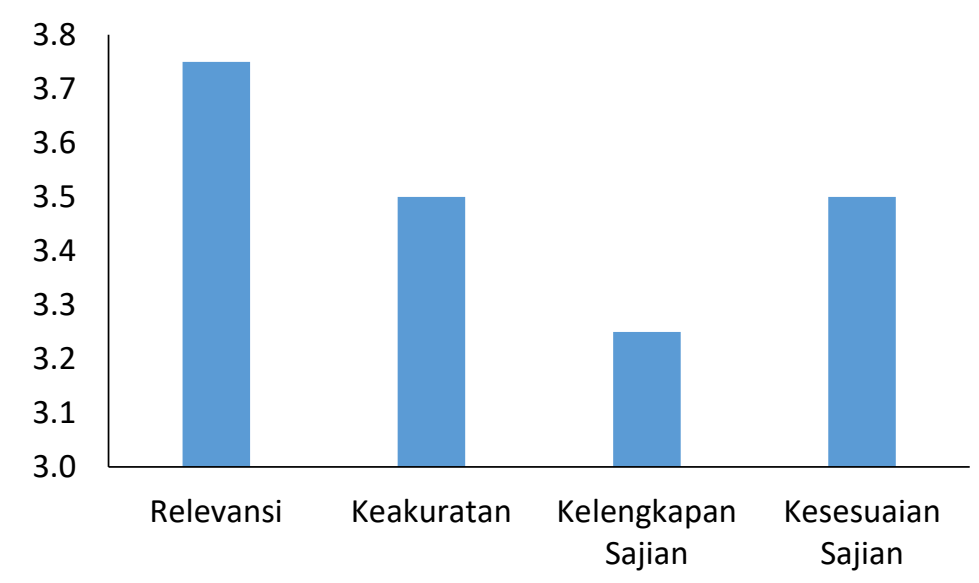

Gambar 4. Grafik rata-rata penilaian tiap aspek pada validasi materi

Pada Gambar 4 dapat diperhatikan bahwa aspek relevansi nilai memperoleh nilai rata-rata sebesar 3,75, aspek keakuratan nilai rata-rata 3,5, aspek kelengkapan sajian 3,25, dan aspek kesesuaian sajian 3,5.

\section{Respon Siswa}

Diseminasi merupakan tahap akhir dari studi konstruksi ini. Lembar kerja siswa yang pekerjaannya telah dievaluasi oleh ahli analisis konten dan media, dan kemudian disebarluaskan melalui uji coba lapangan kecil. Sosialisasi ini hanya dilakukan di SMA Muhammadiyah 7 Kota Yogyakarta pada kelas XI MIPA 1 dengan 19 responden. Dengan menggunakan prinsip Kesadaran Materi Pedagogis Teknis yang telah ditetapkan, distribusi ini bertujuan untuk menguji tanggapan siswa terhadap item LKS dalam gelombang diam dan berjalan. Tujuan akhir dari produk yang dirancang adalah untuk dijual. Hasil penilaian rata-rata respon siswa tiap pernyataan terhadap LKPD dapat dilihat pada Gambar 5.

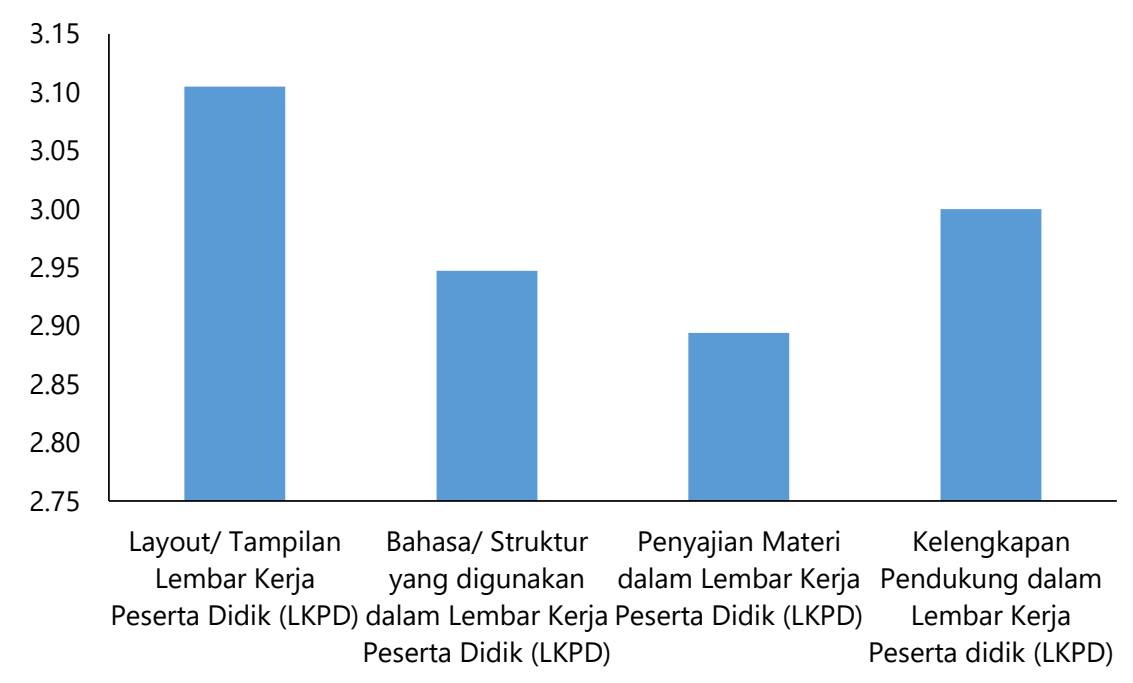

Gambar 5. Grafik rata-rata respon siswa pada setiap pernyataan yang tersaji dalam LKPD 
Hasil respon siswa terhadap lembar kerja peserta didik dengan menggunakan konsep TPACK dalam topik pembelajaran yang digunakan ini dianalisis menggunakan skala likert dengan rentang skor 1 sampai 4. Penggunaan skala likert ini untuk menganalisis hasil respon siswa terhadap LKPD. Respon siswa meliputi aspek Layout/Tampilan (respon siswa $=3,105$ ). Aspek Bahasa/Struktur LKPD mendapat respon sebesar 2,947. Aspek Penyajian Materi mendapat respon sebesar 2,894. Aspek terakhir dalam LKPD, Kelengkapan Pendukung, mendapat respon siswa sebesar 3,00.

\section{Simpulan}

Telah dikembangkan lembar kegiatan peserta didik berbasis TPACK dan di respon sangat baik oleh siswa, juga di validasi sangat baik oleh ahli media dan materi. Sehingga dapat disimpulkan bahwa pengembangan lembar kerja peserta didik dengan menggunakan konsep technological pedagogical and content knowledge ini baik untuk digunakan dan diterapkan dalam kegiatan pembelajaran.

\section{Ucapan terima kasih}

Terima kasih kepada bapak Kepala SMA Muhammadiyah 7 Yogyakarta atas izin untuk melakukan uji coba produk.

\section{References}

Alawiyah, F. (2013). Peran guru dalam kurikulum 2013. Aspirasi: Jurnal Masalah-Masalah Sosial, 4(1), 65-74.

Anggraini, R., Wahyuni, S., \& Lesmono, A. D. (2016). Pengembangan lembar kerja siswa (LKS) berbasis keterampilan proses di SMAN 4 Jember. Jurnal Pembelajaran Fisika, 4(4), 350-357.

Astuti, Y., \& Setiawan, B. (2013). Pengembangan lembar kerja siswa (LKS) berbasis pendekatan inkuiri terbimbing dalam pembelajaran kooperatif pada materi kalor. Jurnal Pendidikan IPA Indonesia, 2(1), 88-92.

Fitriani, W., Bakri, F., \& Sunaryo, S. (2017). Pengembangan lembar kerja siswa (LKS) fisika untuk melatih kemampuan berpikir tingkat tinggi (high order thinking skill) siswa SMA. WaPFi (Wahana Pendidikan Fisika), 2(1), 36-42.

Gorbi Irawan, A., Nyoman Padmadewi, N., \& Putu Artini, L. (2018). Instructional materials development through 4D model. SHS Web of Conferences, 42, 00086.

Haryati, S. (2012). Research and development (R\&D) sebagai salah satu model penelitian dalam bidang pendidikan. Majalah Ilmiah Dinamika, 37(1), 11-26.

Kadi, T., Awwaliyah, R., Nurul, U., \& Paiton, J. (2017). Inovasi pendidikan: Upaya penyelesaian. Jurnal Islam Nusantara, 01(02), 144-155.

Lin, T. C., Tsai, C. C., Chai, C. S., \& Lee, M. H. (2013). Identifying science teachers' perceptions of technological pedagogical and content knowledge (TPACK). Journal of Science Education and Technology, 22(3), 325-336.

Nur, D., \& Putri, P. (2013). Peran kurikulum 2013 dalam meningkatkan mutu pendidikan. Universitas Muhammadiyah Sidoarjo

Pratama, N. S., \& Istiyono, E. (2015). Studi pelaksanaan pembelajaran fisika berbasis higher order thinking (HOTS). In Prosiding Seminar Nasional Fisika dan Pendidikan Fisika (SNFPF), 6, 104-112.

Rosenberg, J. M., \& Koehler, M. J. (2015). Context and technological pedagogical content knowledge (TPACK): A systematic review. Journal of Research on Technology in Education, 47(3), 186-210.

Rosyid, A. (2017). Technological pedagogical content knowledge: Sebuah kerangka pengetahuan bagi guru Indonesia di era MEA. in Prosiding Seminar Nasional Inovasi Pendidikan, 446-454.

Usmeldi. (2015). Pengembangan lembar kerja siswa dalam pembelajaran fisika berbasis riset di SMAN 1 Padang. In Prosiding Seminar Nasional Fisika (E-Journal ), IV , 185-190. 
Wahyudi, B. S., Hariyadi, S., \& Hariani, S. A. (2014). Pengembangan bahan ajar berbasis model problem based learning pada pokok bahasan pencemaran lingkungan untuk meningkatkan hasil belajar siswa kelas X SMA Negeri Grujugan Bondowoso. Pancaran, 3(3), 83-92.

Wardani, D. L., Degeng, I. N. S., \& Cholid, A. (2019). Developing interactive multimedia model 4D for teaching natural science subject. International Journal of Education and Research, 7(1), 63-72. 